\title{
Conducting the Heavenly Chorus: Constituent Contact and Provoked Petitioning in Congress
}

\author{
Geoffrey Henderson, Alexander Hertel-Fernandez, Matto Mildenberger and Leah C. Stokes
}

\begin{abstract}
Congress hears more and more from everyday citizens. How do modern Congressional offices use this information to represent their constituents? Drawing on original interviews and a survey of Congressional staff, we explore how representation works in practice when new data and tools, such as databases and downscaled public opinion polls, are available. In contrast with established theories that focus on responsiveness, we show that representation is a two-way street. Congressional offices both respond to incoming constituent opinion and reach out to elicit opinions from stakeholders. Offices record correspondence into databases, identifying the most salient issues and the balance of opinion among correspondents. They tend not to use polls on policy. To understand the opinions of electorally influential constituencies, staffers also proactively reach out to stakeholders and experts in a practice we call provoked petitioning. If the Washington pressure system is a chorus, Congressional staff often serve as conductors, allowing wellresourced and organized constituents, including interest groups, to sing with the loudest voices. While Congress has some new tools and strategies for representation, its modern practices still reinforce existing biases.
\end{abstract}

Data replication sets are available in Harvard Dataverse at: https://doi.org/10.7910/DVN/ZJ1END

Geoffrey Henderson (10) is a Doctoral Candidate in Political Science at the University of California, Santa Barbara, and a Visiting Graduate Scholar in Political Science at Johns Hopkins University (ghenderson@umail.ucsb.edu). He studies how civic organizations and social movements stimulate political participation and form coalitions, with a focus on the climate justice movement. Geoffrey has studied efforts to engage people in small-dollar campaign finance and environmental activism, how environmental attitudes affect behavior, and how Members of Congress learn their constituents' opinions. His current research examines state-level coalitions of environmental and labor groups advocating for policies to address climate change.

Alexander Hertel-Fernandez is Associate Professor of International and Public Affairs at Columbia University's School of International and Public Affairs (ah3467@columbia.edu). He studies the political economy of the United States, with an emphasis on business, the workplace, labor, and public policy. Recent research focuses on workplace standards, worker rights and collective action. His most recent book, State Capture (Oxford University Press, 2019), examines how conservative donors, activists, and businesses built up cross-state political networks since the 1970s that allowed them to transform state policy and politics — and why progressives lagged behind in their efforts to build liberal state-level clout.

\section{Matto Mildenberger (1) is Assistant Professor of Political Science at the University of California, Santa Barbara} (mildenberger@polsci.ucsb.edu). His research explores the politics of climate change in the United States and around the world. In his research, he draws on comparative political economy and public policy literatures to study the comparative politics of climate change; he also draws on political behavior and public opinion scholarship to study how publics and elites make sense of climate change. His most recent book, Carbon Captured (MIT University Press, 2020), explores how business and labor groups shape climate reforms across advanced economies.

Leah C. Stokes (1) is Assistant Professor of Political Science at the University of California, Santa Barbara (lstokes@ucsb.edu). She works on energy, climate, and environmental politics. Within American Politics, her work focuses on representation and public opinion; voting behavior; and public policy, particularly at the state level. Within environmental politics, she researches climate change, renewable energy, water, and chemicals policy. Her recent book, Short Circuiting Policy (Oxford University Press, 2020), examines the role that utilities have played in promoting climate denial and rolling back clean energy laws. permits unrestricted re-use, distribution, and reproduction in any medium, provided the original work is properly cited. 
n the summer of 2017, Republicans in Congress worked feverishly to repeal President Obama's landmark healthcare law, the Affordable Care Act. Many Republican Senators and Representatives won or retained office campaigning against "Obamacare" (Williamson, Skocpol, and Coggin 2011; Aldrich et al. 2013; Mak 2018). Yet their new plan to "repeal and replace" the law was unpopular, dividing Republican voters (Murray 2017). Moderate Republicans found themselves stuck between an electoral mandate and potential backlash. How did representatives approach this dilemma? Congressional staffers delved into constituent communication databases and compiled the correspondence that offices received about the repeal bill. One chief of staff described the process his office used to track opinion this way:

We put people into three buckets: Those who opposed repeal because they wanted to keep [the ACA]; those who opposed repeal, or the House version of the legislation, because they didn't think it went far enough; and those who supported the bill. ${ }^{1}$

By tallying the e-mails, phone calls and letters that the office received in each category, his staff estimated that a majority of engaged constituents opposed the bill. Lawmakers and their staff also sat down with interest groups to solicit their views, including health insurance companies and the AARP (Gibson 2017; Sullivan 2017).

Understanding whether and how Congress represents the public's policy preferences is a central question in the study of American politics (Wright, Erikson, and McIver 1987; Stimson, MacKuen, and Erikson 1995; Erikson, MacKuen, and Stimson 2002; Canes-Wrone 2015). Past research demonstrates that elected officials' responsiveness to their constituents is highly uneven. Politicians and their staffs tend to measure public opinion imprecisely and therefore misperceive their constituents' preferences (Miller and Stokes 1963; Herbst 1998; Broockman and Skovron 2018; Hertel-Fernandez, Mildenberger, and Stokes 2019). They also respond disproportionately to co-partisans, the affluent, and the organized (Bartels 2008; Gilens 2012; Gilens and Page 2014; Lax, Phillips, and Zelizer 2019; Maks-Solomon and Rigby 2019; Wright and Rigby 2020; Grossmann, Isaac, and Mahmood 2021). Not only do these inequalities mark a departure from the democratic ideal that policy corresponds to majority opinion, they raise questions about how politicians learn about their constituents' views in the first place.

To the degree that the people are sovereign, their influence primarily lies in determining the issues to which offices devote the greatest attention (Bachrach and Baratz 1962; Schattschneider 1975). On salient policy issues, Congressional offices still listen to their most vocal constituents. Yet on the vast majority of issues, constituents are all but silent (Burstein 2014). When Congressional offices are not hearing from constituents, they reach out to the organized groups representing constituencies with a stake in the policy at hand (Monroe 2001; Miler 2007). Indeed, political elites often conceptualize public opinion as synonymous with interest groups (Herbst 1998). As one legislative director put it:

In the cases where stakeholders and constituents are not engaged on an issue, those are the issues where you reach out to people and say this is going to affect you, get your act together. Those are cases where we're more proactive, because we want to hear from somebody. ${ }^{2}$

From education to healthcare to energy, Congressional staff seek out the people who are "living under the law," requesting their opinions on proposed legislation. ${ }^{3}$ This "provoked petitioning" challenges conventional models of lobbying that put the focus on interest groups reaching out to elected officials (Bombardini and Trebbi 2020). Representatives and their staff do not merely respond to contact from organized interests, but elicit opinions, contributing to the mobilization of bias in the political system (Pitkin 1967; Schattchneider 1975; Disch 2012; Schlozman, Verba, and Brady 2012). Offices maintain regular contact with interest group representatives, seek out civic association meetings in the constituency, and pay close attention to the questions that constituents raise at town halls.

In this paper, we describe how the contemporary Congress undertakes representation in practice. We draw on both original interviews and a survey of senior Congressional staff to examine how offices learn their constituents' priorities and preferences. Congress has a suite of modern tools to gauge constituent preferences: databases to record and track constituent correspondence, including e-mails; public opinion polls, including downscaled estimates from multi-level regression with poststratification (MRP) models that permit district-level opinion estimates; in-person meetings with constituents and group representatives; and town hall meetings (Grimmer, Westwood, and Messing 2015; Hersh 2015; Hager and Hilbig 2020; Sekar 2020). However, offices rely far more on some tools than others. Despite the widespread attention polling gets in the news and public discourse (Leeper 2019), members of Congress rarely use polls to ascertain their constituents' views on policy. Instead, offices rely on the same methods observed decades ago (Fenno 1977; Kingdon 1984), relying on politically active constituents and interest groups. Congressional staff use sophisticated constituent correspondence databases to respond to the constituents most likely to shape their re-election prospects; tend to discount or ignore the mass campaigns that advocacy groups organize online; and rely on interest groups for advice on legislative decisions. As a result, the incoming and outgoing channels of information on constituents' preferences paint a picture that disproportionately reflects the views of the vocal and the organized. Despite Congress's ability to use modern tools to conduct the chorus of 
representation, their methods still give the loudest singing roles to voices with a "strong upper-class accent" (Schattschneider 1975).

\section{The Mechanisms of Representation}

For over half a century, political scientists have debated whether politicians respond to public preferences on policy. Research has focused on the conditions under which public preferences matter, and to whom politicians are most likely to respond (Downs 1957; Miller and Stokes 1963; Schattschneider 1975; Canes-Wrone 2015). Although policy rarely aligns perfectly with public opinion, evidence suggests that representatives change policies in response to shifts in the public's ideological leanings (Wright, Erikson, and McIver 1987; Stimson 1991; Stimson, MacKuen, and Erikson 1995; Lax and Phillips 2012; Caughey and Warshaw 2018). Such responsiveness is encouraging for democratic accountability.

However, a growing body of research has uncovered some troubling patterns. Representatives often respond more to wealthy citizens, interest groups, and members of their own political parties than to the public writ large (Bartels 2008; Gilens 2012; Gilens and Page 2014; Lax, Phillips, and Zelizer 2019; Stokes 2020). After controlling for affluent Americans' and interest groups' preferences, scholars do not find a relationship between the middle class's preferences and public policy decisions (Gilens and Page 2014; Bowman 2020). Representatives are also more likely to be responsive to non-minority than minority constituents (Butler and Broockman 2011; Broockman 2013; Butler 2014; Costa 2017), a bias that cannot be explained by the demographic composition of representatives' districts (Einstein and Glick 2017; Mendez and Grose 2018). More broadly, these distortions suggest that there is not a simple link between public opinion and policy.

To understand representation, we must attend to mechanisms. How do politicians gather information to estimate the public's preferences? Political staff play a central role (Salisbury and Shepsle 1981; Montgomery and Nyhan 2017; Hertel-Fernandez, Mildenberger, and Stokes 2019). In response to Congress' increased complexity and workload, lawmakers have delegated critical tasks to aides based in the District of Columbia (Hall 1996). Legislators also have offices in their districts and states staffed by field representatives assigned to particular geographies or issues (Monroe 2001). These national and constituency-based staffers gather policy-relevant information; communicate with constituents, interest groups, and government agencies; and advise members on legislative decisions such as votes, co-sponsorships, and legislative participation (Hall 1996; Costa 2020). As Miler (2010, 27) argues, political staff are "the primary link between the legislative office and constituents, as well as between the office and organized interests in the policy community."

Understanding the tools and procedures staffers use is all the more important given how new technology may be reshaping the process of representation. In an era of widespread polling, presidents have devoted substantial resources to tracking-and shaping-public opinion (Jacobs and Shapiro 1995; Druckman and Jacobs 2006; Hager and Hilbig 2020; Stokes 2020). Yet Congressional representatives do not enjoy a similar supply of information. State- and district-specific polls are both expensive and uncommon, and when they exist, are more likely to be horse-race polls during elections (Herbst 1998). Surveys of state politicians running for elected office, for instance, find that a majority do not conduct polls (Broockman and Skovron 2018). Partially as a result, politicians and their staff misestimate their constituents' opinions as measured by polls, even on highly salient issues like healthcare (Broockman and Skovron 2018; Hertel-Fernandez, Mildenberger, and Stokes 2019).

If not through polls, how do politicians and their staff measure public opinion? Before widespread Internet adoption, research suggested they read newspaper editorials, paid attention to the topics covered in the media, met with trusted constituents, and listened for comments and questions at public meetings in the constituency (Fenno 1977; Kingdon 1984). However, with some exceptions (Hager and Hilbig 2020), contemporary research has not squarely addressed the question of how politicians estimate public preferences. Moreover, most theories of representation do not distinguish between incoming and outgoing information. We know that Congressional offices are not equally interested in the opinions of all constituents. Like other political actors, Congressional offices flatten the world, focusing the issues that are most relevant to their desired ends. In this sense, representatives conceptualize constituent opinion primarily as a roadmap to achieving their goal of staying in office (Mayhew 1974). For example, in the two years before they are up for re-election, there is evidence that senators are about twice as responsive to shifts in public opinion (Warshaw 2016). Representatives have an incentive to respond disproportionately to constituencies whose votes, time, and money might help them in their next campaign (Mayhew 1974; Fenno 1977; Aldrich 1995; Skinner 2007). For instance, Congressional offices are more likely to accept meeting requests—and to schedule higher-level meetings - when constituents requesting the meeting identify as a campaign donor (Kalla and Broockman 2016). To get ahead of the electorate, politicians also work to identify constituents' preferences on electorally salient issues, and avoid taking positions that could provoke an electoral backlash (Arnold 1990). This strategy leads members to follow not only the direction of constituent opinion but also its intensity. Representatives therefore seek out the opinions 
of engaged constituents who are more likely to notice their policy decisions and hold them accountable (Downs 1957; Bawn et al. 2012).

However, Congressional offices have incomplete information about who potential donors, volunteers, and voters might be. Congressional staff therefore use political activists as a proxy for the people who are most likely to support their campaign in the next election. Constituents who call the Washington office or attend a town hall meeting signal their potential for future involvement in electoral activity (Wright 1996). These individuals may then stand in for the preferences of larger groups of constituents. Hence, Congressional offices learn how the public feels about salient issues from constituents who engage in "information-rich" forms of political participation (Griffin and Newman 2005).

Indeed, prior research shows that staffers are more likely to identify stakeholders on a given bill from subsets of their constituency who donate and contact the office at high rates. Miler (2007) asks legislative staffers in House offices to identify the sub-constituencies in their districts with a stake in each of two specific healthcare reform bills. She finds that staffers are "more likely to see those constituents," such as physicians, "who contact them and who make financial contributions" (Miler 2007, 598, 619). Bartels (2008) demonstrates that U.S. senators are more likely to respond to constituents who contact them. Further, Leighley and Oser (2018) find that non-voting participation predicts congruence in policy preferences between the constituent and their representative at all income levels, suggesting that disproportionate responsiveness to wealthy citizens does not result from affluence alone. And Congressional staff themselves report paying close attention to the most active constituents and incorporating that information in recommendations to members. The vast majority of staffers responding to a Congressional Management Foundation survey said that constituent visits, mail, questions raised at town hall meetings, and "contact from a constituent who represents other constituents" have at least some influence on members who are undecided on the issue in question (CMF 2011).

Interest groups, particularly those with a reputation for representing and persuading electorally influential constituencies, are another important source of information for Congress (Downs 1957; Hansen 1991). When they lack information on the priorities and preferences of a particular constituency, members of Congress rely on trusted interest groups to represent this inaccessible group's views (Herbst 1998; Miler 2010; Grossmann 2012). However, interest groups may not accurately represent public preferences, but instead present a biased picture that aligns with their own interests (Kollman 1998; Jacobs and Shapiro 2000; Hertel-Fernandez 2018; Stokes 2020). As we will argue, this dynamic is compounded when legislative staff engage in targeted outreach to interest groups.

\section{Data and Methods}

To understand how Congress learns about constituents' preferences, we conducted semi-structured interviews with eighteen senior Congressional staff between August and October 2017. These interviews ranged from $20 \mathrm{~min}$ utes to 1.5 hours and were conducted either in persontypically in their member's Washington office-or over the phone. Due to senior staffers' limited availability, we used a combination of purposive, network, and random sampling to select interviewees. We first reached out to the 101 staffers who had responded to a survey of senior Congressional staff that we had conducted the previous year, expecting these staff would be more receptive to our request. Second, at the end of each interview we asked the subject to refer us to other senior staffers who might be willing to participate. Third, we reached out to a random sample of senior Congressional staff. We randomly selected senior staffers from a list of all chiefs of staff, deputy chiefs of staff, legislative directors, and senior policy advisors for every member of Congress as of July 2016. These efforts yielded a sample of eighteen interviews with thirteen chiefs of staff, four legislative directors, and one senior policy advisor. Eleven respondents worked for Democratic members of Congress, while seven worked for Republicans. In our findings, we both anonymize interviewees' names and only present information that could not plausibly be used to identify them. To preserve interviewees' confidentiality, we refer to them only by their title and a letter, and sometimes by whether they work for a member in the House or the Senate.

Our sample of Democratic staff is highly representative of offices in terms of member ideology. The mean DW-NOMINATE score for Democratic offices in our sample is $-0.37(\mathrm{SD}=0.10)$, compared with an average score of $-0.38(\mathrm{SD}=0.12)$ among Democratic offices in the 115th Congress. Our sample of Republicans skews more conservative than the caucus writ large during the 115th Congress. The mean DW-NOMINATE score for Republican offices in our sample is $0.63(\mathrm{SD}=0.33)$, compared with an average score of $0.49(\mathrm{SD}=0.15)$ among Republican offices (McCarty, Poole, and Rosenthal 2006; Lewis et al. 2020). Our interview sample also skews heavily toward the House of Representatives, with fifteen House and only three Senate staffers. Finally, it is always possible that individuals who agreed to an interview about constituent communication hold systematically different views about this issue than individuals who do not. This is particularly the case among the sample we recruited from staffers who had previously replied to our elite survey. However, our interviews request discussed the role of staff in Congress generally, rather than issues of constituent communication narrowly. 
Our sampling strategy targeted the crucial staff connecting constituents with their elected representatives. The chief of staff is the highest-ranking staffer in a Congressional office, presiding over a wide variety of responsibilities. When we asked one chief of staff about his role, he jokingly replied, "Yes, all of them." ${ }^{4}$ These staffers manage, hire, and supervise staff. They also ensure that the legislative team is advancing the Member's policy goals, oversee the offices in the district or state, and lead communications. Additionally, and separate from these official roles, many chiefs of staff serve as campaign managers, spearheading their bosses' fundraising efforts. ${ }^{5}$ Legislative directors have a narrower portfolio but conduct no less important work. They manage a team of legislative assistants seeking to advance the member's policy priorities by keeping informed on the Congressional agenda, advising the member on votes and co-sponsorship decisions, and developing legislation. ${ }^{6}$ Finally, senior policy advisors-more common in the Senate than in the House-can take on a diverse range of duties depending on the member's needs. They may focus on a particular legislative area, aid the member's work on a given committee, or work on projects relating to the constituency. ${ }^{7}$

Our interviews focused on how Congressional offices collect information on constituent opinion, and staffers' roles in policy decisions. We also explored how staff interpret and convey information about constituent opinion to members of Congress and how the public's preferences are reflected in policy. We did this using a variant of the grounded theory approach (Glaser and Strauss 1967; Charmaz 2006). Grounded theory involves analyzing qualitative data through an inductively created list of codes that reflect themes in interviews. We read over each interview transcript, highlighted text relating to one of the codes we had identified, and compiled all relevant evidence for each topic across interviews. In this way, the two main mechanisms of representation we describe in our study - constituent contact and provoked petitioningwere derived inductively.

In conducting these interviews, we were mindful that staffers might have deliberate or unconscious reasons to respond strategically to our questions, including offering responses that cast themselves, their members, or their parties favorably. At the same time, we offered confidentiality to our survey respondents, providing fewer incentives to respond in ways intended to cast them as individuals or their offices in an especially favorable light. Even more importantly, our inductive research design did not depend on testing competing explanations for staffers' behavior, but rather uncovering from their own thinking an understanding of legislative staff practices. Our sampling strategy also prioritizes senior staff, whose practices may not reflect staff with less experience in Congress. ${ }^{8}$
We supplemented our interviews with a survey of Congressional staff, which we have described and analyzed more comprehensively in other work (Hertel-Fernandez, Mildenberger, and Stokes 2019). In August 2016, we e-mailed a survey to all senior staff in Congress, including staff with the following titles: Chief of Staff, Deputy Chief of Staff, Legislative Director, and Senior Policy Advisor. Our approach produced a sample of 101 respondents representing 91 offices, resulting in a response rate of $9.6 \%$, similar to other surveys of Congressional staff (CMF 2011). Our sample resembles the general population of senior Congressional staff on various observable characteristics. Staff in Democratic offices are slightly overrepresented in the survey sample, constituting 54\% of our sample. Even so, we have enough Republicans in our sample to conduct disaggregated analyses by party. Importantly, the offices for which our respondents worked were representative of Congress more broadly in terms of ideology, as indicated by DW-NOMINATE scores (Carroll et al. 2015; Hertel-Fernandez, Mildenberger, and Stokes 2019).

\section{Representatives Respond and Provoke: How Congressional Offices Estimate Constituent Opinion}

Understanding constituent opinion is central to Congressional offices' work. Almost half of Hill offices have reported diverting resources from other functions toward keeping track of constituent correspondence (CMF 2011). In our survey, we asked staffers to identify their most important considerations when advising on legislative decisions. As figure 1 shows, staffers on both sides of the aisle report that constituent opinion and communications are paramount. Compared to any other input, the largest number of senior Congressional staffers reported these as an important consideration when advising the member on legislative decisions.

Offices are far more concerned with opinion in the member's constituency than with national public opinion. Consistent with Fenno's (1977) concept of the "geographic constituency," staff universally defined a constituent as a resident of the member's district or state. Only $20 \%$ of Democratic staffers and 33\% of Republican staffers reported that national public opinion was an important consideration when advising the member. In contrast, $76 \%$ of Democratic staffers and $86 \%$ of Republican staffers said that public opinion in their constituency was important. Our surveys and interviews also indicated that constituent opinion information flows from the bottom up-from constituents to the offices-and from the top down-with offices eliciting information from constituents (table 1). The next sections describe these two practices in turn. 


\section{Figure 1}

\section{Staff considerations when advising member.}

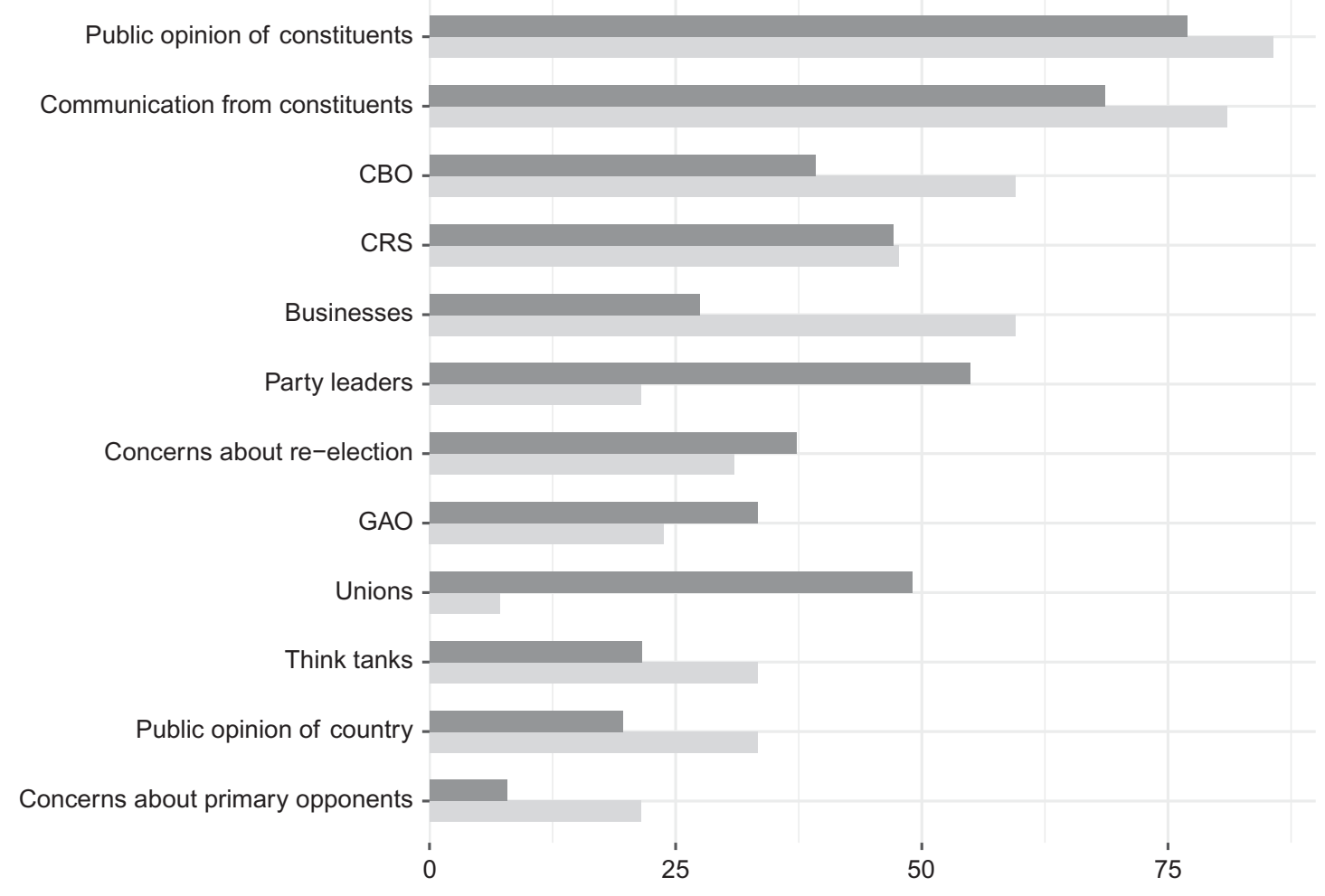

$\%$ staffers reporting item as important consideration

Democrat Republican

Figure 1 displays the results from the following question: "Think about the policy proposals you have worked on during your time on the Hill. What shaped your thinking on whether your member should support or oppose these policies? Indicate how important each of the following considerations was in shaping your advice to your member on various policy proposals." Response options included "Not all that important," "Slightly important," "Moderately important," "Very important," and "Extremely important." The dark grey bars represent the percentage of Democratic staffers indicating that a given consideration was at least "Very important," while the light grey bars indicate the percentage of Republican staffers providing this response.

\section{Table 1}

\section{Common methods for learning about constituent opinion}

\begin{tabular}{lll}
\hline Incoming Contact & $\begin{array}{c}\text { Two-Way } \\
\text { Information Flows }\end{array}$ & Outgoing Contact \\
\hline $\begin{array}{l}\text { Constituent correspondence (phone calls, letters, } \\
\text { e-mail messages, etc.) }\end{array}$ & $\begin{array}{c}\text { Civic association } \\
\text { meetings } \\
\text { Town halls } \\
\begin{array}{l}\text { Visits to the office from constituents and } \\
\text { stakeholders }\end{array}\end{array}$ & $\begin{array}{c}\text { Members' and staffers' visits to the } \\
\text { constituency } \\
\text { Outreach to stakeholders and experts, } \\
\text { "provoked petitioning" }\end{array}$ \\
\hline
\end{tabular}

\section{How Congressional Offices Receive, Organize, and Respond to Constituent Contact}

To represent the interests of their constituents, Congressional offices must constantly gather incoming information to evaluate public preferences. However, constituencies are complex. As Fenno (1977) argues, members of Congress do not see their constituencies as an "undifferentiated glob." Districts and states comprise a host of demographic groups, interest groups, voters and non-voters, co-partisans, and supporters of other parties. 
How do offices isolate a meaningful signal from this noise?

In their efforts to make their constituencies legible for electoral purposes, Congressional offices rely on some tools more than others. Perhaps surprisingly, given their nearconstant presence in the media, Congressional offices reported in interviews that they rarely polled their constituents on specific issues or estimated constituency-level opinion from national surveys. A few staffers noted that they occasionally conducted representative opinion polls, but not with the regularity necessary to maintain up-to-date public opinion estimates. ${ }^{9}$ One chief of staff expressed that it would be ideal to conduct surveys to measure the opinions of a representative sample of their constituency, but that their office lacked the resources. ${ }^{10}$ Moreover, recent work suggests that staffers are disinterested in polling results even when they are available (Kalla and Porter 2020).

Instead, constituent correspondence is a central source of public opinion data for Congress. Offices keep track of constituent phone calls, e-mails, and letters in a database. Virtually all use software from Lockheed Martin, Fireside21, or IQ - three private-sector companies specializing in constituent relationship management platforms - to record and compile correspondence from constituents, sometimes merged with information from other public and commercial sources, including voter files (Hersh 2015; Emerling et al. 2017). ${ }^{11}$ These software platforms emerged in the 1990s and have become more sophisticated over time.

Staffers enter e-mail messages, letters, and phone calls into these systems, ${ }^{12}$ and many offices use contact information to screen out correspondents who are not constituents. ${ }^{13}$ Some staffers we interviewed also reported that their office uses the database to record the names of constituents who have attended town hall meetings or other public events. ${ }^{14}$ The software allows correspondence to be labeled by topic and direction. Many offices aggregate correspondence within issue areas to calculate total volume and relative amount of supportive and opponent contact the office has received on an issue over a given time period. $^{15}$

After coding their data, staffers use these databases to construct images of their constituents' preferences. They query their databases to understand which issues are salient and to measure the balance of opinion. The latter practice is very common before a vote on a bill or a speech on that topic. While most successful legislation is still bipartisan, many votes fall along party lines (Curry and Lee 2019). ${ }^{16}$ Yet constituent opinion can influence members' decisions, including where to invest their scarce legislative time and energy. Constituent correspondence can help set the Congressional agenda for politicians, suggesting issues to elevate, which bills to co-sponsor, and how to vote on legislation that cuts across party lines. ${ }^{17}$
Our staffer survey also provides evidence that constituent correspondence can have a clear effect on the legislative process. We asked staffers to imagine that their office was considering a bill under debate in Congress, and had received letters expressing opinions on the bill. We provided respondents information on these letters, randomly assigning respondents to different conditions. The survey question read as follows, with the different treatments shown in square brackets:

Imagine your office is considering a bill that is under debate in Congress.

- Your office receives [2/20/200] letters from constituents [supporting/opposing] this bill.

- The letters have very [similar/different] wording to one another.

- The letter writers identify themselves as [constituents/ employees of a large company based in your constituency/members of a non-profit citizens group].

Respondents reported, on a four-point scale, how likely they would be to mention these letters to the member, how significant these letters would be in their advice to the member on the bill, and how representative of their constituents they would consider the letters to be. Given our small sample, we pool our analysis across treatment conditions, that is, comparing levels within each of the three treatment conditions rather than each condition individually. ${ }^{18}$ (For instance, we compare the difference between an office receiving 2, 20, or 200 letters, pooling across all other treatment conditions.)

Nearly two-thirds of staffers said they would be at least somewhat likely to mention relevant letters to the member when advising them on a bill, and more than half said these letters would be at least somewhat significant to their advice. However, while our interviews indicate that members' co-sponsorships and legislative priorities sometimes arise from constituent correspondence-particularly when policies impose visible and salient costs on constituentsstaffers generally do not consider such correspondence to be representative. ${ }^{19}$ Across all treatment conditions, only about four in ten respondents said that they would consider the letters to be at least somewhat representative of constituents. These results underscore that staffers recognize that their methods of constituent opinion estimation are systematically biased toward particular subsets of their constituencies. We summarize the full results of the experiment in table 2.

We find that the volume of letters, the wording of the letters, and the identities of the letter-writers all impacted staffers' reported actions. The volume of letter-writers affected the likelihood that staffers would mention the letters to the member. On a four-point scale, staffers receiving twenty letters were nearly one point $(0.92)$ more 


\section{Table 2}

\section{Constituent communication experiment}

\begin{tabular}{|c|c|c|c|}
\hline Condition & $\begin{array}{l}\text { How Likely to Mention to } \\
\text { MC? }\end{array}$ & $\begin{array}{l}\text { How Significant in Advice to } \\
\text { MC? }\end{array}$ & $\begin{array}{l}\text { How Representative of Public } \\
\text { Opinion? }\end{array}$ \\
\hline \multicolumn{4}{|l|}{$\begin{array}{l}\text { Number of } \\
\text { letters }\end{array}$} \\
\hline 2 & $2.08(0.81)$ & $2.12(0.78)$ & $1.92(0.76)$ \\
\hline 20 & $3.00(0.87)$ & 2.67 (0.66) & 2.38 (0.73) \\
\hline 200 & $3.44(0.85)$ & $2.81(0.74)$ & $2.59(0.64)$ \\
\hline \multicolumn{4}{|l|}{ Position } \\
\hline Opposing & $2.97(1.04)$ & $2.67(0.87)$ & $2.33(0.81)$ \\
\hline Supporting & $2.77(0.97)$ & $2.44(0.67)$ & $2.29(0.71)$ \\
\hline \multicolumn{4}{|l|}{ Wording } \\
\hline Different & $3.09(1.00)$ & $2.76(0.71)$ & $2.32(0.74)$ \\
\hline Similar & $2.59(0.96)$ & $2.3(0.78)$ & $2.3(0.78)$ \\
\hline \multicolumn{4}{|l|}{ Identity } \\
\hline Constituents & $2.92(0.94)$ & $2.53(0.74)$ & $2.23(0.65)$ \\
\hline Employees & 3.00 (1.04) & $2.76(0.74)$ & $2.62(0.73)$ \\
\hline \multicolumn{4}{|l|}{ Group } \\
\hline members & 2.53 (1.07) & $2.24(0.83)$ & $1.94(0.83)$ \\
\hline
\end{tabular}

Notes: The table summarizes the mean and standard deviation (in parentheses) for each treatment condition in the survey experiment, with responses ranging from one to four (with greater values indicating greater likelihood, significance, and representativeness).

likely to mention the letters than staffers receiving only two letters $(\mathrm{SE}=0.23, \mathrm{p}<0.01)$. Staffers receiving two hundred letters were 0.44 points more likely to mention the letters than staffers receiving twenty letters $(\mathrm{SE}=0.23$, $\mathrm{p}<0.1)$. Second, higher correspondence volume increased the significance of the letters in staffers' advice to the member. On a four-point scale, staffers receiving twenty letters considered the letters 0.55 points more significant than staffers receiving only two letters $(\mathrm{SE}=0.19, \mathrm{p}<$ 0.01 ). However, we do not find a statistically significant difference in the significance of the letters between staffers receiving twenty and two hundred letters (DIM $=0.15$, $\mathrm{SE}=0.19, \mathrm{p}=0.43)$. Third, the more letters staffers receive, the more they consider them representative of constituent opinion - up to a point. On a four-point scale, staffers receiving twenty letters considered the letters 0.46 points more representative than receiving only two letters $(\mathrm{SE}=0.20, \mathrm{p}<0.05)$. However, we do not find a statistically significant difference in perceptions of representativeness between staffers receiving twenty and two hundred letters $(\mathrm{DIM}=0.21, \mathrm{SE}=0.18, \mathrm{p}=0.25)$.

Our experiment also demonstrates that staffers systematically discount similarly worded letters, which may signal an advocacy campaign involving little effort on the part of the letter-writers. We do not find evidence that staffers perceive similarly worded letters as less representative of the constituency (DIM=-0.02, $\mathrm{SE}=0.17, \mathrm{p}=0.90$ ). However, they are less likely to mention similarly worded letters to the member, and these letters are less significant in their advice. Staffers receiving similarly worded letters are 0.49 points less likely to mention them $(\mathrm{SE}=0.22$, $\mathrm{p}<0.05$ ), and deem the letters 0.46 points less significant $(\mathrm{SE}=0.16, \mathrm{p}<0.01)$.
Our interview data confirm that staffers disregard messages from online advocacy campaigns, considering them unrepresentative of constituents' views. ${ }^{20}$ Staffers pay little heed to pre-written form emails. One chief of staff recalled that his office once responded to a constituent's message only for the constituent to reply that they had never contacted the office; apparently, the constituent had forgotten they had signed their name on a form e-mail. ${ }^{21}$ In the House, mass online mailings from advocacy groups arrive through a system called Communicating with Congress. This system, which was developed in conjunction with the Congressional Management Foundation, brings contact from advocacy campaigns into office databases via a separate channel. The inspiration was a unified system through which advocacy campaign mailings could be sorted by office. However, having a separate channel may unintentionally allow offices to discount form letters from advocacy campaigns.

By contrast, Congressional offices pay more attention when they perceive a substantial number of constituents putting a significant investment of time and energy into a given issue. A few of our interviewees mentioned that their offices seek to understand their voters' priorities by identifying the issues constituents have organized around. ${ }^{22}$ One legislative director said that he could tell a particular issue was important to constituents based on the amount of groups in the district working on the issue, and the level of constituent activism, including fly-ins to lobby the member on Capitol Hill. ${ }^{23}$ Some staffers we interviewed also mentioned that they take note of issues people ask questions about at town halls and civic association meetings. ${ }^{24}$

Hence, current practices within Congressional offices do not focus on tracking constituents' general policy 
mood, as previous scholarship has proposed (Erikson, MacKuen, and Stimson 2002). Instead, offices track constituent opinion on specific issues. Offices also give more weight to contact that takes more resourcesexpressing an opinion on a specific issue, showing up to town halls or member's offices, calling or writing independently_all practices that are easier for affluent and well-organized constituents (Schlozman, Verba, and Brady 2012). While constituents' views on salient issues can help inform staffers' advice to their member, our evidence suggests that organized groups' views are more commonly factored into legislative decisions. One of the first steps legislative staff take when preparing advice is to "spend time figuring out who the stakeholders are" to identify their positions on the proposal. ${ }^{25}$ When advising the member on votes and co-sponsorships, it is common practice for staff to mention interest groups' positions on the legislation in question. ${ }^{26}$

Results from our survey similarly suggest that interest groups play an important role in shaping staffers' recommendations. We presented staffers with a list of national interest groups and asked how important these groups' positions, resources, and information were when considering legislation. Groups identified as "very important" by at least a quarter of staffers included, for Republicans: the NRA, the U.S. Chamber of Commerce, the National Association of Manufacturers, the Heritage Foundation, and the Club for Growth; and for Democrats: the AFLCIO, the League of Conservation Voters, the Center for American Progress, the Sierra Club, and Everytown for Gun Safety. When we asked staff to identify the groups other offices mentioned when trying to persuade their member to vote a certain way on a bill, economic interest groups figured prominently in staffers' responses, including the Chamber of Commerce, the AFL-CIO, and the National Association of Manufacturers. Overall, offices develop significant relationships with interest groups across a range of policy issues.

Interest groups have also developed new tactics to strengthen their influence in Congress. Businesses recognize that constituent contact figures prominently in Congressional offices' perceptions of public opinion. Hence they often mobilize their employees or other grassroots constituencies (like customers or suppliers) to reach out to their representatives (Hertel-Fernandez 2018; Walker 2009; Stokes 2020). Among other forms of contact from businesses, we asked respondents how useful they would find correspondence from a business's employees when deliberating over legislation. Respondents could indicate whether a given form of contact was not at all, slightly, moderately, very, or extremely useful (figure 2). ${ }^{27}$ Around a third of staffers considered correspondence from a business's employees to be very or extremely useful. In our prior research, we found that Congressional staff consider letters from employees of a large business in the member's constituency to be more representative of constituent opinion than letters from self-identified constituents or members of a citizen group (Hertel-Fernandez, Mildenberger, and Stokes 2019). The weight Congressional staff assign to letters from employees is striking. Just as the mechanisms of representation amplify the voices of politically engaged individuals, they also give interest groups' demands greater resonance within the policymaking process. In the next section, we describe how Congressional offices proactively invite interest groups and other stakeholders to weigh in on legislative decisions.

\section{Provoked Petitioning: How Congressional Offices Reach Out to Stakeholders}

Standard accounts of lobbying and constituent representation suggest a one-way relationship: interest groups and constituents request meetings with legislators or their staff to influence member behavior on legislation. ${ }^{28}$ However, our interviews emphasize that lobbying is a two-way street: staff also acquire information on constituent opinion by proactively reaching out to key constituencies. In part, Congressional offices reach out because they hear little to nothing from constituents on many issues. ${ }^{29}$ Staff recognize that this silence does necessarily represent the level of public engagement; as one chief of staff asserted, "If we haven't heard from people, it may not indicate a lack of interest." 30

To address this information shortfall, senior Congressional aides often rely on an outgoing method of information-gathering which we call "provoked petitioning." This practice involves reaching out to constituents - often members or representatives of organized groups-for information on key constituencies' priorities, preferences, and problems. First, offices seek to identify constituents' priorities - the issues that are most likely to matter come election season. Second, offices seek to learn constituents' preferences on specific, salient issues or individual pieces of legislation. Third, offices seek to gather information about the problems on the legislative agenda. As one chief of staff put it, an office will conduct outreach to answer the following questions: "Have you heard of this?", "How important is it?", and "Do you have a view on this?" 31

To identify constituents' priorities, offices dispatch staff to meetings and events in the district to engage with politically active constituents. District staff regularly attend the meetings of civic associations such as rotary clubs, county boards of supervisors, and local chambers of commerce. ${ }^{32}$ It is also common practice for many members to hold town hall meetings with constituents, either in person or remotely (Bradner 2017). ${ }^{33}$ One chief of staff described a public event in the constituency involving a panel of speakers on an issue of interest to constituents, noting that the district staff would record the questions 


\section{Figure 2}

\section{Usefulness of business contact strategies for legislative advice.}

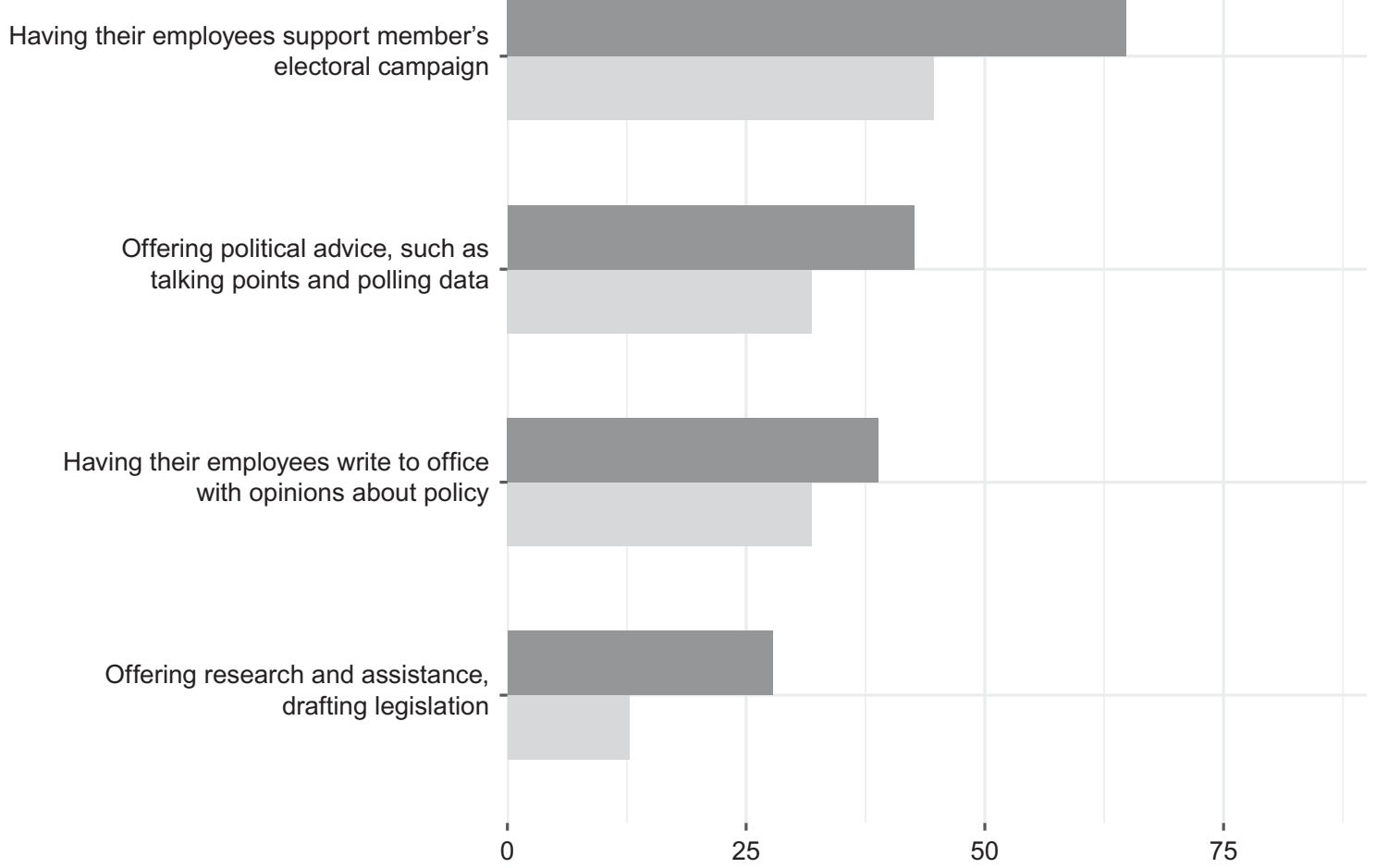

$\%$ staffers reporting business contact strategy as useful

Democrat

Republican

The figure displays responses to the following question: "Businesses often contact Congressional offices to support or oppose policy proposals. Thinking about the ways that businesses have contacted your office about policy proposals in the past year, which strategies have been most useful to your office as you deliberate over legislation?" Respondents could indicate that such strategies were "Not at all useful," "Slightly useful," "Moderately useful," "Very useful," or "Extremely useful." The dark grey bars represent the percentage of Democratic staffers reporting that a particular strategy was at least "Very useful," while the light grey bars indicate the percentage of Republican staffers providing this response.

that constituents raised. Although he remarked that the attendees represented a small sample of the member's constituents, he reasoned that they "took time out of their day" to participate, implying that their questions are worthy of special consideration. ${ }^{34}$ Another chief of staff agreed, asserting that there is a relatively small group of "civically active" constituents who attend various kinds of public meetings. While acknowledging that these people are not representative of the constituency, he posited that these constituents are "relied upon to give information" about politics to their neighbors, and therefore "maybe they're more important than the other 719,000 people." After attending these meetings, staffers report to the member the issues that constituents are talking about. ${ }^{35}$ In this way, politically active constituents' priorities stand in for the priorities of voters writ large. Creative members looking for even more opportunities to elicit constituent opinion supplement town halls with other formats such as mobile district office hours, in which the member sets up a temporary office in their constituency, inviting constituents to present casework or proposals for legislation. ${ }^{36}$

Provoked petitioning can also inform offices about constituents' preferences on salient issues. ${ }^{37}$ One legislative director described a time when a letter from a constituent voiced concern about a change in a federal law. A staffer was assigned to reach out to people-even beyond the member's district-and learned that there was a "growing constituency nationwide that didn't like the change that had been made." As a result of staffers' meetings with constituents opposed to the change, the 
member introduced a bill to undo it. Similarly, when his office decided to develop legislation that would affect a particular industry, he started by reaching out to firms within the industry for their opinions on the kind of legislation that could be introduced. ${ }^{38}$ Provoked petitioning also helps offices learn constituents' positions, alleviate their concerns, and ensure that they are satisfied with the member's performance. One chief of staff explained that he tries "to expose [the member] to both sides of [an] issue so he can hear from the stakeholders themselves what their position is." ${ }^{39}$ Staffers may also reach out to groups when the Member plans to vote for a bill that an influential group opposes, but wants to "let them know that we're thinking about them." ${ }^{40}$

Finally, Congressional offices reach out to people and organizations that they consider to have expertise on the problems on the legislative agenda. Legislative staff specializing in a given area frequently seek out reports on the issue in question from interest groups and think tanks. ${ }^{41}$ One chief of staff noted that her boss would call or visit the authors of studies addressing the topic of the legislation he was developing. ${ }^{42}$ Just as Congressional offices specifically seek to learn the opinions of their constituents, they seek to understand how policy proposals would affect their district or state. ${ }^{43}$

How do offices determine that a constituency is sufficiently important to conduct provoked petitioning? Constituents who stand to be affected by a policy loom large in Congressional staffers' mental models of their districts and states. Staffers used the term "stakeholder" in our interviews with sufficient regularity to suggest that it represents a common shorthand on Capitol Hill. The term "stakeholder" is often used to refer to an interest group, but the definition is broader than this. One chief of staff offered perhaps the most precise definition when he mentioned that his office seeks to consult people "who are actually living under the law." ${ }^{4} 4$ A stakeholder is a constituency, or a member or representative of that group, which stands to gain or lose from a given policy or proposal. A stakeholder can be an interest group, a government official, a public employee, a business owner, a member of a civic association, or simply a constituent who believes that a policy may affect them.

These stakeholders are central to Congress's decisionmaking process. One chief of staff described a process of consulting various sources to prepare a vote recommendation on an education bill. A staffer might speak with teachers' unions and school advocates, as well as school administrators or the state government. ${ }^{45}$ A legislative director recounted a time when their member was approached to sponsor legislation affecting a particular industry. After listening to the organization supporting the bill, the office sought to identify the range of stakeholders. The legislative staff met with industry groups, reached out to several relevant organizations in the member's state, and wrote a memo for the member explaining which stakeholders were in favor of the bill and which were opposed. ${ }^{46}$ Importantly, many of these contacts were solicited; in these cases, the office, rather than the stakeholder, took the initiative. ${ }^{47}$ Thus, the process of gathering constituent opinion information gives stakeholders disproportionate influence relative to the average constituent.

Over time, staffers build a network of relationships with stakeholders who they can consult when they want to better understand particular issues or constituencies. ${ }^{48}$ Multiple chiefs of staff used a form of the word "trust" when describing the groups or individuals to whom they reach out when preparing to advise the member on a given issue. ${ }^{49}$ Not only do those who gain this trust acquire the ability to access Congressional offices, these offices come to rely on them for political intelligence. Staffers reach out to advocates that they "know and work with." ${ }^{\circ 0}$ Staffers turn to these stakeholders when they lack information about the potential reception of a policy proposal among the constituency which the stakeholder represents. One chief of staff reported that the member would ask the legislative director to describe stakeholders' positions on legislation prior to voting. ${ }^{51}$ Another mentioned that every time the member seeks to introduce legislation, his office will reach out to stakeholders for their views. ${ }^{52}$

While provoked petitioning can involve national interest groups, Congressional offices often rely on stakeholders based in the member's district or state. Members and their staff often visit businesses on their trips home, asking the company's leaders how policies would affect them. ${ }^{53}$ Further, field representatives in the district or state offices are tasked with interacting regularly with organizations based in the constituency such as local chambers of commerce, service groups, trade associations, businesses (especially large employers), and labor unions. One chief of staff described it this way:

[We have a] regular channel of communication between the field representatives and the D.C. office ... [A field representative may be] out meeting with this pharmaceutical company, and they're concerned about this [regulation that is] about to be sent out for comment, and when they hear that they'll make sure that the person in D.C. who has that issue area is informed about what's going on, and [the staff in D.C. will] work with the folks back in the state to make sure they're fully informed of [their] concerns. ${ }^{54}$

Contact with stakeholders in the district or state allows Congressional offices to ensure that the advice they receive from national interest groups does not conflict with their constituency's interests. One chief of staff noted that his office reaches out to firms in the member's state to ensure that national-level trade associations are taking positions in line with state-level firms, to ensure their "concerns are addressed in whatever piece of legislation that we' re working on." 55 Conversely, when constituency-based stakeholders lack a position, staffers tend to consult national interest groups who are more engaged on the issue. ${ }^{56}$ 
Provoked petitioning thus allows staffers to ensure that their advice to the member reflects the positions of organized groups with a stake in the proposal.

Of course, provoked petitioning is not the only, or even the most frequent, way in which Congressional offices reach out to constituents. Offices also proactively attempt to shape opinions and demonstrate how the member is responding to constituents (Grimmer, Westwood, and Messing 2015). Relying on their correspondence databases, Congressional staff-typically, legislative assistants and legislative correspondents-identify the issues on which they are hearing a great deal from constituents. Once staff determine that an issue is highly salient, they begin sorting relevant correspondence into a "batch" within the correspondence database. ${ }^{57}$ Staff then write a response to the constituents who contacted the office about the issue, typically outlining the member's position and action on the issue in question. ${ }^{58}$ One legislative director added that for key constituencies, the office will "find something to e-mail them about" to maintain contact on a regular basis. ${ }^{59}$ Thus, Congressional offices do not merely respond to their constituents' preferences; they proactively shape the priorities and preferences of issue publics within their constituency, helping to bring certain interests into being (Pitkin 1967; Disch 2012; Lenz 2012).

\section{Conducting the Heavenly Chorus}

Describing Washington in the mid-twentieth century, Schattschneider famously wrote that the "heavenly chorus sings with a strong upper-class accent." Subsequent research has shown that this problem persists. Disparities in economic resources, including along racial lines, have helped interest groups exert undue influence over government officials (Hacker and Pierson 2010; Schlozman, Verba, and Brady 2012; Hertel-Fernandez 2018). However, as Pitkin (1967) observed during Schattschneider's era, politicians do not merely respond to their constituencies. By invoking particular groups and interests, elected officials help bring these constituencies into being (Disch 2012).

In this paper, we have explored how Congressional offices both assemble and conduct the heavenly chorushelping to bring out its distinctly upper-class accent. While Congressional offices respond to contact from constituents - both individuals and organized groupsthey also frequently elicit such contact to learn constituents' views, a practice we describe as "provoked petitioning." If constituent correspondence privileges the affluent and organized because they are closer to the microphone, provoked petitioning amplifies this bias by handing interest groups a megaphone.

Despite the proliferation of instruments for estimating constituent opinion, such as downscaled national opinion polling, Congressional offices tend to rely on tools that perpetuate old biases. Offices process and organize constituent correspondence to identify salient issues and estimate the prevailing opinion on these issues among politically engaged constituents based on the volume of contact and its direction. They supplement this information with advice from organized groups. In the frequent cases when offices' demand for information exceeds their supply, they reach out to stakeholders on a given bill or issue to learn. Staffers develop networks of relationships with trusted groups perceived to have a vested interest in the issues of the day, and rely on them for guidance in developing legislation, casting votes, and co-sponsoring legislation. They consequently rely on interest groups and politically active constituents to stand in for the opinions of their constituents writ large.

Of course, information about constituent opinion accounts for only some of the members' behavior regarding votes, co-sponsorships, and where to invest scarce legislative resources. Staffers' recommendations on legislation also incorporate a series of factors beyond constituent opinion, including party agendas, policy analysis, economic impacts on their district or state, consistency with prior votes, other members' positions, and the president's position. ${ }^{60}$ Further, members make many legislative decisions independently of their staffs. Lawmakers often lobby each other directly to co-sponsor, take action, or vote a certain way on legislation. ${ }^{61}$ Many co-sponsorships also originate from other offices reaching out to a member's legislative staff. ${ }^{62}$ In these situations, staffers' recommendations - and the knowledge that informs them-play an important role.

Our findings shed light on several major and interrelated developments in contemporary American politics: economic inequality, systemic racism, and partisan polarization. First, politically active constituents are disproportionately affluent and well organized, and groups with few resources are unlikely to organize and participate in politics (Schlozman, Verba, and Brady 2012, 123, 280). When less affluent constituents voice their concerns to public officials, they are more likely than their wealthier counterparts to call attention to "issues of basic human need" such as poverty and jobs (Schlozman, Verba, and Brady 2012). If offices listen primarily to active constituents and interest groups, this may contribute to representatives' disproportionate responsiveness to the wealthy (Schattschneider 1975; Bartels 2008; Gilens 2012; Gilens and Page 2014). Because non-Hispanic whites comprise a disproportionate share of affluent Americans, the messages representatives hear from constituents are likely also distorted along the dimension of race.

Not only is the average political participant unrepresentative in terms of race and class, politically active constituents also tend to have more extreme or intense preferences. Strong partisans and those with homogeneous political discussion networks are especially likely to participate in politics (Mutz 2006, 123; Rosenstone and Hansen 1993, 155), and the ideological gap is widening 
between Republican and Democratic "activists" and other citizens (Jacobson 2000). In addition to strong partisans, people with personal commitments to policy outcomes (e.g., Social Security recipients) are more likely to participate (Campbell 2003; Han 2009). We might expect that these people are likely to hold intense preferences and unlikely to favor compromise. Due to their focus on the most politically active constituents, Congressional offices may perceive the public to be more polarized than it is in practice (Fiorina, Abrams, and Pope 2011). In turn, this perception might help explain why both Democratic and Republican members of Congress are more ideologically extreme than their constituents (Bafumi and Herron 2010).

We are not advocating a radical change in Congressional staffers' methods of tracking public opinion. Given the electoral incentives and resource constraints that Congressional offices face, in the near term such changes are unrealistic (Furnas et al. 2020; LaPira, Drutman, and Kosar 2020). Meanwhile, as public opinion researchers have documented, polls have many problems of their own-question wording and order effects, non-response bias, and social desirability bias, to name a few (Hacker and Pierson 2005; Achen and Bartels 2016). And there are normative reasons to give greater weight to the views of participants who are most vocal, as these participants might have the most at stake in a policy debate. As the case of the civil rights or LGBT rights campaigns illustrate, majority public opinion can lag behind movements pushing for urgent social change (Page and Shapiro 1992). Still, our results point towards important questions for scholars of representation. Surveys should include a more diverse range of questions to elicit more information about the patterns and scope of provoked petitioning. This work will allow for clearer statements about the generalizability and representativeness of the findings we discuss in this paper. At the same time, scholars should also work towards surveying local interest groups, businesses and targeted constituents to understand how these actors engage with communications from their representative. Once we recognize that the dynamics of representation occur in two directions, important new empirical avenues become apparent.

More broadly, what is necessary is the reconstitution of civic infrastructure. The decline in mass-membership-based organizations representing lower- and middle-class Americans has diminished the political voice those Americans command (Putnam 2000; Skocpol 2003; Feigenbaum, HertelFernandez, and Williamson 2018). Research has shown that civic associations, such as community organizations and labor unions, can boost the political participation of otherwise unlikely citizens (Skocpol 2003; Osterman 2006; Han 2009). For all constituents' opinions to inform legislative decisions and actions, we need a stronger array of intermediary organizations that can ensure that Americans have the opportunity to voice their views to their elected officials.

\section{Acknowledgements}

The Dirksen Congressional Center provided funding for the project through its Congressional Research Grant program.

\section{Notes}

1 Interview with Chief of Staff I. In our findings, we both anonymize interviewees' names and only present information that could not plausibly be used to identify them. To preserve interviewees' confidentiality, we refer to them only by their title and a letter, and sometimes by whether they work for a member in the House or the Senate.

2 Interview with Legislative Director C.

3 Interview with Chief of Staff K.

4 Interview with Chief of Staff J.

5 Interviews with Chiefs of Staff A, J, K, M.

6 Interview with Legislative Director B.

7 Interview with Senior Policy Advisor A.

8 However, Hertel-Fernandez, Mildenberger, and Stokes 2019 do not find that staff with more experience on the Hill have more accurate perceptions of their members' constituents.

9 Interviews with Chiefs of Staff B, E, H, Legislative Director A

10 Interview with Chief of Staff J.

11 Congressional offices typically use these software systems to send generic e-mail responses to every constituent who has contacted them on a given issue.

12 Interviews with Chief of Staff B, Legislative Director D.

13 Interview with Chief of Staff $\mathrm{H}$.

14 Interview with Chief of Staff C.

15 Interviews with Chief of Staff I, Legislative Director C.

16 Given partisan polarization and strong party leadership (Rohde 1991), the "vast majority of votes" are "no-brainers" (Chief of Staff B, Legislative Director B). As one legislative director put it, "there are fundamental partisan disagreements on the role of government," and therefore "a basic understanding of the boss's views makes the vote recommendation automatic" (Legislative Director B). Even when a bill is not so "cut and dry" from a partisan or ideological standpoint, oftentimes offices can rely on the member's past voting behavior as a guide for how to vote. In these cases, constituent opinion appears to play less of a role, if any, in informing congressional offices' recommendations to the member on how to vote (Chief of Staff L, Legislative Directors A, C). However, some offices regularly provide the member with reports regarding constituent opinion on the most salient issues with a view to preparing the member for statements and votes (Chiefs of Staff H, M). 
17 Analysis of constituent opinion information is part of a broader process of agenda-setting in Congressional offices. The legislative team communicates with other offices, reads "Dear Colleague" e-mails, follows the news, and looks for other clues about the major pieces of legislation advancing to the floor or up for co-sponsorship. When a legislative staffer becomes aware of a bill that they consider worthy of attentioneither for co-sponsorship or because the voting decision is ambiguous - the staffer will flag it and organize a team to write a memorandum for the member. These memos typically originate with the legislative assistant tasked with the policy area in question, and move up the chain to the legislative director, sometimes to a senior policy advisor, and finally to the chief of staff. Some offices supplement these memos with weekly meetings at which the major legislative decisions for the coming week are discussed. Interviews with Legislative Director D and Chief of Staff A.

18 Sample sizes for each treatment condition as follows. Number of letters: $2(n=29), 20(n=35), 200(n=$ 37). Position: oppose $(n=53)$, support $(n=48)$.

Similarity: different $(n=51)$, similar $(n=50)$. Identity: constituents $(n=44)$, employees $(n=36)$, members of citizens group $(n=21)$.

19 Interviews with Chiefs of Staff G, H, Legislative Directors B, C, D.

20 Interviews with Chiefs of Staff F, L, Legislative Directors C, D.

21 Interview with Chief of Staff F. The Congressional Management Foundation estimates that 53\% of staffers believe that "most advocacy campaigns of identical form messages are sent without constituents' knowledge or approval"; Congressional Management Foundation 2011, 5. This practice has become increasingly common in recent years; Walker 2009; Karpf 2012.

22 Interviews with Chief of Staff J, Legislative Director B.

23 Interview with Legislative Director B.

24 Interviews with Chiefs of Staff $\mathrm{C}$ and $\mathrm{E}$.

25 Interview with Legislative Director A.

26 Interviews with Chiefs of Staff C, G, I, H, Legislative Director C.

27 The question was worded: "Businesses often contact Congressional offices to support or oppose policy proposals. Thinking about the ways that businesses have contacted your office about policy proposals in the past year, which strategies have been most useful to your office as you deliberate over legislation?"

28 While Hansen 1991 describes legislators' demand for information about constituent preferences, he conceptualizes the legislator as "granting access" to petitioning groups, rather than proactively inviting groups to share their intelligence. See also Kalla and Broockman 2016.
29 Interview with Chief of Staff I.

30 Interview with Chief of Staff G.

31 Interview with Chief of Staff G.

32 Interviews with Chiefs of Staff D, H.

33 Interview with Chief of Staff $\mathrm{H}$.

34 Interview with Chief of Staff C.

35 Interview with Chief of Staff $\mathrm{H}$.

36 Interview with Chief of Staff E.

37 Interviews with Chiefs of Staff K, L, Legislative Director A.

38 Interview with Legislative Director C.

39 Interview with Chief of Staff J.

40 Interview with Legislative Director B.

41 Interviews with Chiefs of Staff B, E, M.

42 Interview with Chief of Staff E.

43 Interviews with Chiefs of Staff C, F, Legislative Director C.

44 Interview with Chief of Staff $\mathrm{K}$.

45 Interviews with Chiefs of Staff C, L.

46 Interview with Legislative Director A.

47 Interview with Chief of Staff L.

48 Interviews with Chief of Staff K, Legislative Director C.

49 Interviews with Chiefs of Staff B, G, K.

50 Interviews with Chiefs of Staff B, C, E.

51 Interview with Chief of Staff G.

52 Interview with Chief of Staff L.

53 Interviews with Chiefs of Staff B, M.

54 Interview with Chief of Staff $M$.

55 Interview with Chief of Staff K.

56 Interview with Legislative Director C.

57 Interviews with Chiefs of Staff I, L.

58 Interviews with Chiefs of Staff B, H, I, Legislative Director A.

59 Interview with Legislative Director A.

60 Interviews with Chiefs of Staff B, C, G, I, H, Legislative Director C.

61 Interviews with Legislative Directors C and D.

62 Interview with Legislative Director D.

\section{References}

Achen, Christopher H., and Larry M. Bartels. 2016. Democracy for Realists: Why Elections Do Not Produce Responsive Government. Princeton, NJ: Princeton University Press.

Aldrich, John H. 1995. Why Parties? The Origin and Transformation of Political Parties in America. Chicago: University of Chicago Press.

Aldrich, John H., Bradford H. Bishop, Rebecca S. Hatch, D. Sunshine Hillygus, and David W. Rohde. 2013. "Blame, Responsibility, and the Tea Party in the 2010 Midterm Elections.” Political Behavior 36(3): 471-91.

Arnold, R. Douglas. 1990. The Logic of Congressional Action. New Haven, CT: Yale University Press. 
Bachrach, Peter, and Morton S. Baratz. 1962. "Two Faces of Power." American Political Science Review 56(4): 947-52.

Bafumi, Joseph, and Michael C. Herron. 2010. "Leapfrog Representation and Extremism: A Study of American Voters and Their Members in Congress." American Political Science Review 104(3): 519-42.

Bartels, Larry M. 2008. Unequal Democracy: The Political Economy of the New Gilded Age. Princeton, NJ: Princeton University Press.

Bawn, Kathleen, Martin Cohen, David Karol, Seth Masket, Hans Noel, and John Zaller. 2012. "A Theory of Political Parties: Groups, Policy Demands and Nominations in American Politics." Perspectives on Politics 10(3): 571-97.

Bombardini, Matilde, and Francesco Trebbi. 2020. "Empirical Models of Lobbying." Annual Review of Economics 12: 391-413.

Bowman, Jarron. 2020. "Do the Affluent Override Average Americans? Measuring Policy Disagreement and Unequal Influence." Social Science Quarterly 101 (3): 1018-37.

Bradner, Eric. 2017. "Republicans Decide: To Town Hall or Not to Town Hall?" CNN, April 14.

Broockman, David E. 2013. "Black Politicians Are More Intrinsically Motivated to Advance Blacks' Interests: A Field Experiment Manipulating Political Incentives.” American Journal of Political Science 57(3): 521-36.

Broockman, David E., and Christopher Skovron. 2018. "Bias in Perceptions of Public Opinion among Political Elites." American Political Science Review 112(3): 542-63.

Burstein, Paul. 2014. American Public Opinion, Advocacy, and Policy in Congress. New York: Cambridge University Press.

Butler, Daniel M. 2014. Representing the Advantaged: How Politicians Reinforce Inequality. New York: Cambridge University Press.

Butler, Daniel M., and David E. Broockman. 2011. "Do Politicians Racially Discriminate Against Constituents? A Field Experiment on State Legislators." American Journal of Political Science 55(3): 463-77.

Campbell, Andrea Louise. 2003. How Policies Make Citizens: Senior Political Activism and the American Welfare State. Princeton, NJ: Princeton University Press.

Canes-Wrone, Brandice. 2015. "From Mass Preferences to Policy." Annual Review of Political Science 18(1): 147-65.

Carroll, Royce, Jeff Lewis, James Lo, Nolan McCarty, Keith Poole, and Howard Rosenthal. 2015. "DWNOMINATE Scores with Bootstrapped Standard Errors.” Dataset available online at: https:// legacy.voteview.com/dwnomin.htm. Updated September 17, 2015.
Caughey, Devin, and Christopher Warshaw. 2018. "Policy Preferences and Policy Change: Dynamic Responsiveness in the American States, 1936-2014." American Political Science Review 112(2): 249-66.

Charmaz, Kathy. 2006. Constructing Grounded Theory: A Practical Guide through Qualitative Analysis. London: SAGE Publications.

Congressional Management Foundation (CMF). 2011. "Communicating with Congress: Perceptions of Citizen Advocacy on Capitol Hill." Partnership for a More Perfect Union. Washington, DC: CMF.

Costa, Mia. 2017. "How Responsive Are Political Elites? A Meta-Analysis of Experiments on Public Officials." Journal of Experimental Political Science 4(3): 241-54.

Costa, Mia. 2020. "Citizen Evaluations of LegislatorConstituent Communication." British Journal of Political Science. DOI: https://doi.org/10.1017/ S0007123419000553

Curry, James M., and Frances E. Lee. 2019. "Non-Party Government: Bipartisan Lawmaking and Party Power in Congress." Perspectives on Politics 17(1): 47-65.

Disch, Lisa. 2012. "Democratic Representation and the Constituency Paradox." Perspectives on Politics 10(3): 599-616.

Downs, Anthony. 1957. "An Economic Theory of Political Action in a Democracy." Journal of Political Economy 65(2): 135-50.

Druckman, James N., and Lawrence R. Jacobs. 2006. "Lumpers and Splitters: The Public Opinion Information That Politicians Collect and Use." Public Opinion Quarterly 70(4): 453-76.

Einstein, Katherine Levine, and David M. Glick. 2017. "Does Race Affect Access to Government Services? An Experiment Exploring Street Level Bureaucrats and Access to Public Housing." American Journal of Political Science 61(1): 100-16.

Emerling, Danielle, Hope Bibens, Natalie Bond, John Caldwell, and Alison White. 2017. "Archiving Constituent Services Data of the U.S. Congress.” A report of the Society of American Archivists Congressional Papers Section CSS/CMS Task Force. (https://www2.archivists.org/sites/all/files/2017_CSS_ CMS_Report.pdf)

Erikson, Robert S., Michael B. MacKuen, and James A. Stimson. 2002. The Macro Polity. New York: Cambridge University Press.

Fenno, Richard F. 1977. "U.S. House Members in Their Constituencies: An Exploration." American Political Science Review 71(3): 883-917.

Feigenbaum, James, Alexander Hertel-Fernandez, and Vanessa Williamson. 2018. "From the Bargaining Table to the Ballot Box: Political Effects of Right to Work Laws." NBER Working Paper No. 24259. DOI: $10.3386 /$ w24259 
Fiorina, Morris P., Samuel J. Abrams, and Jeremy C. Pope. 2011. Culture War? The Myth of a Polarized America. 3rd ed. London, UK: Pearson Longman.

Furnas, Alexander C., Lee Drutman, Alexander HertelFernandez, Timothy M. LaPira, and Kevin R. Kosar. 2020. "The Congressional Capacity Survey: Who Staff Are, How They Got There, What They Do, and Where They Go." In Congress Overwhelmed: The Decline in Congressional Capacity and Prospects for Reform, eds., Timothy M. LaPira, Lee Drutman, and Kevin R. Kosar. Chicago: University of Chicago Press.

Gilens, Martin. 2012. Affuence and Influence: Economic Inequality and Political Power in America. Princeton, NJ: Princeton University Press.

Gilens, Martin, and Benjamin I. Page. 2014. "Testing Theories of American Politics: Elites, Interest Groups, and Average Citizens." Perspectives on Politics 12(3): 564-81.

Glaser, Barney G., and Anselm L. Strauss. 1967. The Discovery of Grounded Theory: Strategies for Qualitative Research. Chicago: Aldine Publishing Company.

Griffin, John D., and Brian Newman. 2005. "Are Voters Better Represented?” Journal of Politics 67(4): 1206-27.

Grimmer, Justin, Sean J. Westwood, and Solomon Messing. 2015. The Impression of Influence: Legislator

Communication, Representation, and Democratic Accountability. Princeton, NJ: Princeton University Press.

Grossmann, Matt. 2012. The Not-So-Special Interests: Interest Groups, Public Representation, and American Governance. Palo Alto, CA: Stanford University Press.

Grossmann, Matt, William Isaac, and Zuhaib Mahmood. 2021. "Political Parties, Interest Groups, and Unequal Class Influence in American Policy." Journal of Politics. DOI: https://doi.org/10.1086/711900

Hacker, Jacob S., and Paul Pierson. 2005. "Abandoning the Middle: The Bush Tax Cuts and the Limits of Democratic Control." Perspectives on Politics 3(1): 33-53.

Hacker, Jacob S., and Paul Pierson. 2010. WinnerTake-All Politics: How Washington Made the Rich Richer-And Turned Its Back on the Middle Class. New York: Simon \& Schuster.

Hager, Anselm, and Hanno Hilbig. 2020. "Does Public Opinion Affect Political Speech?" American Journal of Political Science 64(4): 921-37.

Hall, Richard L. 1996. Participation in Congress. New Haven, CT: Yale University Press.

Han, Hahrie. 2009. Moved to Action: Motivation, Participation and Inequality in American Politics. Palo Alto, CA: Stanford University Press.

Hansen, John Mark. 1991. Gaining Access: Congress and the Farm Lobby, 1919-1981. Chicago: University of Chicago Press.

Herbst, Susan. 1998. Reading Public Opinion: How Political Actors View the Democratic Process. Chicago: University of Chicago Press.
Hersh, Eitan D. 2015. Hacking the Electorate: How Campaigns Perceive Voters. New York: Cambridge University Press.

Hertel-Fernandez, Alexander. 2018. Politics at Work: How Companies Turn Their Workers into Lobbyists. Oxford: Oxford University Press.

Hertel-Fernandez, Alexander, Matto Mildenberger, and Leah C. Stokes. 2019. "Legislative Staff and Representation in Congress." American Political Science Review 113(1): 1-18.

Jacobs, Lawrence R., and Robert Y. Shapiro. 1995. “The Rise of Presidential Polling: The Nixon White House in Historical Perspective." Public Opinion Quarterly 59(2): 163-95.

Jacobs, Lawrence R., and Robert Y. Shapiro. 2000. Politicians Don't Pander: Political Manipulation and the Loss of Democratic Responsiveness. Chicago: University of Chicago Press.

Jacobson, Gary C. 2000. "Party polarization in national politics: the electoral connection." In Polarized Politics: Congress and the President in a Partisan Era, eds. J.R. Bond and R. Fleisher, 9-30. Washington, DC: CQ Press.

Kalla, Joshua L., and David E. Broockman. 2016. "Campaign Contributions Facilitate Access to Congressional Officials: A Randomized Field Experiment." American Journal of Political Science 60 (3): 545-58.

Kalla, Joshua L., and Ethan Porter. 2020. "Correcting Bias in Perceptions of Public Opinion Among American Elected Officials: Results from Two Field Experiments." British Journal of Political Science. DOI: https://doi.org/10.1017/S0007123419000711

Karpf, David. 2012. The MoveOn Effect: The Unexpected Transformation of American Political Advocacy. New York: Oxford University Press.

Kingdon, John W. 1984. Agendas, Alternatives, and Public Policies. Boston: Little, Brown.

Kollman, Ken. 1998. Outside Lobbying: Public Opinion and Interest Group Strategies. Princeton, NJ: Princeton University Press.

LaPira, Timothy M., Lee Drutman, and Kevin R. Kosar. 2020. Congress Overwhelmed: The Decline in Congressional Capacity and Prospects for Reform. Chicago: University of Chicago Press.

Lax, Jeffrey R., and Justin H. Phillips. 2012. "The Democratic Deficit in the States." American Journal of Political Science 56(1): 148-66.

Lax, Jeffrey R., Justin H. Phillips, and Adam Zelizer. 2019. "The Party or the Purse? Unequal Representation in the U.S. Senate." American Political Science Review 113(4): 917-40.

Leeper, Thomas J. 2019. "Where Have the Respondents Gone? Perhaps We Ate Them All." Public Opinion Quarterly 83(S1): 280-88. 
Leighley, Jan E., and Jennifer Oser. 2018.

"Representation in an Era of Political and Economic Inequality: How and When Citizen Engagement Matters." Perspectives on Politics 16(2): 328-44.

Lenz, Gabriel S. 2012. Follow the Leader? How Voters Respond to Politicians' Policies and Performance. Chicago: University of Chicago Press.

Lewis, Jeffrey B., Keith Poole, Howard Rosenthal, Adam Boche, Aaron Rudkin, and Luke Sonnet. 2020. Voteview: Congressional Roll-Call Votes Database. (https://voteview.com)

Mak, Tim. 2018. "Koch Brothers, Behind Tea Party Wave, Face Democrats' Rising Tide In 2018.” NPR, January 30.

Maks-Solomon, Cory, and Elizabeth Rigby. 2019. "Are Democrats Really the Party of the Poor? Partisanship, Class, and Representation in the U.S. Senate." Political Research Quarterly. (https://doi.org/10.1177\% 2F1065912919862623)

Mayhew, David R. 1974. Congress: The Electoral Connection. New Haven, CT: Yale University Press.

McCarty, Nolan, Keith T. Poole, and Howard Rosenthal. 2006. Polarized America: The Dance of Ideology and Unequal Riches. Cambridge, MA: MIT Press.

Mendez, Matthew, and Christian Grose. 2018. "Doubling Down: Inequality in Responsiveness and the Policy Preferences of Elected Officials." Legislative Studies Quarterly 43(3): 457-91.

Miler, Kristina C. 2007. "The View from the Hill: Legislative Perceptions of the District." Legislative Studies Quarterly 32(4): 597-628.

Miler, Kristina C. 2010. Constituency Representation in Congress: The View from Capitol Hill. New York: Cambridge University Press.

Miller, Warren E., and Donald E. Stokes. 1963. "Constituency Influence in Congress." American Political Science Review 57(1): 45-56.

Monroe, J.P. 2001. The Political Party Matrix: The Persistence of Organization. Albany: State University of New York Press.

Montgomery, Jacob M., and Brendan Nyhan. 2017. "The Effects of Congressional Staff Networks in the U.S. House of Representatives." Journal of Politics 79(3): 745-61.

Murray, Mark. 2017. "Poll: 48 Percent Say House GOP Health Care Bill Is a Bad Idea." NBC News, May 14.

Mutz, Diana C. 2006. Hearing the Other Side: Deliberative versus Participatory Democracy. New York: Cambridge University Press.

Osterman, Paul. 2006. "Overcoming Oligarchy: Culture and Agency in Social Movement Organizations." Administrative Science Quarterly 51: 622-49. (https:// doi.org/10.2189/asqu.51.4.622)
Page, Benjamin I., and Robert Y. Shapiro. 1992. The Rational Public: Fifty Years of Trends in Americans' Policy Preferences. Chicago: University of Chicago Press.

Pitkin, Hanna. 1967. The Concept of Representation. Berkeley, CA: University of California Press.

Putnam, Robert D. 2000. Bowling Alone: The Collapse and Revival of American Community. New York: Simon and Schuster.

Rohde, David W. 1991. Parties and Leaders in the Postreform House. Chicago: University of Chicago Press.

Rosenstone, Steven J., and John Mark Hansen. 1993. Mobilization, Participation, and Democracy in America. New York: MacMillan Publishing Company.

Salisbury, Robert H., and Kenneth A. Shepsle. 1981. "U. S. Congressman as Enterprise.” Legislative Studies Quarterly 6(4): 559-76.

Schattschneider, E.E. 1975. The Semisovereign People: A Realist's View of Democracy in America. Rev. ed. Boston: Thomson Learning.

Schlozman, Kay Lehman, Sidney Verba, and Henry E. Brady. 2012. The Unheavenly Chorus: Unequal Political Voice and the Broken Promise of American Democracy. Princeton, NJ: Princeton University Press.

Sekar, Samantha. 2020. "Understanding Misrepresentation: How Policymakers Perceive Signals from Constituents on Environmental Policies." Unpublished manuscript. (https://osf.io/bhzd4/ download)

Skinner, Richard M. 2007. More Than Money: Interest Group Action in Congressional Elections. Lanham, MD: Rowman \& Littlefield.

Skocpol, Theda. 2003. Diminished Democracy: From Membership to Management in American Civic Life. Norman: University of Oklahoma Press.

Stimson, James A. 1991. Public Opinion in America: Moods, Cycles, and Swings. Oxford, UK: Westview Press.

Stimson, James A., Michael B. MacKuen, and Robert S. Erikson. 1995. "Dynamic Representation.” American Political Science Review 89(3): 543-65.

Stokes, Leah C. 2020. Short Circuiting Policy: Interest Groups and the Battle Over Clean Energy and Climate Policy in the American States. Oxford: Oxford University Press.

Sullivan, Peter. 2017. "Insurance Lobbyists Meet GOP Staff on ObamaCare repeal.” The Hill, June 21.

Walker, Edward T. 2009. "Privatizing Participation: Civic Change and the Organizational Dynamics of Grassroots Lobbying Firms." American Sociological Review 74(1): 83-105.

Warshaw, Christopher. 2016. "Responsiveness and Election Proximity in the United States Senate." Unpublished manuscript. (http://www.chriswarshaw. com/papers/senate_representation_160524.pdf) 
Williamson, Vanessa, Theda Skocpol, and John Coggin. 2011. "The Tea Party and the Remaking of Republican Conservatism." Perspectives on Politics 9(1): 25-43.

Wright, Gerald C., and Elizabeth Rigby. 2020. "Income Inequality and State Parties: Who Gets Represented?" State Politics and Policy Quarterly. (https://doi.org/ 10.1177\%2F1532440020912461)
Wright, Gerald C., Robert S. Erikson, and John P. McIver. 1987. "Public Opinion and Policy Liberalism in the American States." American Journal of Political Science 31(4): 980-1001.

Wright, John R. 1996. Interest Groups and Congress: Lobbying, Contributions, and Influence. London: Pearson. 